\title{
Activist Women's Political Participation in East Kalimantan Governor Election 2008-2018
}

\author{
Ida Wahyuni Iskandar' ${ }^{1}$, Zaid bin Ahmad $^{2}$ \\ \{idaharsono77@yahoo.com ${ }^{1}$, zayyadal@hotmail.com²\} \\ Faculty of Social and Politics Science, Mulawarman University, Samarinda, Indonesia ${ }^{1}$, Faculty of \\ Human Ecology, University Putra Malaysia, Serdang, Selangor, Malaysia ${ }^{2}$
}

\begin{abstract}
Democracy today faces many challenges including political inequality. Women have been deliberately excluded from political power and participation in democracies. Various studies explained about women's participation in various countries. This paper attempts to study political participation among women in Indonesia in Pemilihan Kepala Daerah (local election) specifically in East Kalimantan. The study employed a qualitative approach and conducted in-depth interviews with relevant key informants as data collection method. Besides voting, there are various political participation form for women in Pilkada. By knowing the various forms of political participation such as voting, campaign, political discussion and contacting, it can be better to analyze the true nature of women's political participation. Lack of participation in various forms of political participation analyses helping determine steps for governments, political parties, and community organizations to increase women's political participation.
\end{abstract}

Keywords: Pilkada; political participation; women participation

\section{Introduction}

By allowing the regions to have more say in running their own affairs, it was hoped that local people would benefit from local government policies; in this sense, decentralization is a major and necessary step towards nurturing a flourishing local democracy because it opens up spaces for local political participation [1]. Democracy today faces many challenges: increasing political inequality, the decline of widespread political participation, voter incompetence, etc [2]. The participation of community is very important because the theory of democracy states that the community knows what they want. Civil rights and freedoms are respected and upheld. There is no democracy without people's political participation.

Historically, women have been deliberately excluded from political power and participation in democracies, and differentials in participation have often persisted even with the removal of formal barriers to voting and holding office [3]. According to Dreze \& Sen [4], increased citizen participation can be especially challenging for women, who often face numerous constraints (e.g. social costs for speaking in public, limited access to information, and a weak sense of political efficacy) to voicing their preferences in such forums. Various studies explained about women's participation in various countries. The equality of women's participation in politics is of concern to many countries. Studies say there are still inequalities in political participation between women and men. Studies highlighted, that women are seen to have fewer resources of 
time, money, civic skills, and they are considered to demonstrate lower psychological engagement in politics than men [5].

Indonesian women asserted that it was essential that women participate in politics in order that woman's issues, people's welfare, and the nation's living standards, become matters of concern. "Women have special needs that can only be understood by women themselves, for instance, issues of reproductive health, family welfare, children's education, children's wellbeing, and household chores'. Being a wife and mother is indeed important, and these roles should be prioritized, but they should not prohibit women's involvement in political life, or try to contain women's political participation to sectors deemed "women's affairs" [6].

In recent years, parties and parliaments have responded to growing national and international pressure to increase women's political presence by introducing reform measures, such as gender quotas, aimed at increasing the selection and election of female candidates [7]. In more than fifty countries, quotas requiring that a certain minimum of the parties' candidates for election to national parliament must be women are now stipulated in major political parties' own statutes [8]. Even though it has been regulated in the Law, women's participation in politics is still minimal. Basically, quota $30 \%$ per hundred given for women's involvement in politics and women's representation in parliament mandated by Law No. 10 of 2008 concerning Legislative Elections and Law No. 2 of 2008 concerning Political Parties, still very far from the reality.

According to the East Kalimantan Women's Empowerment and Child Protection Agency, the IDG (Gender Empowerment Index) in East Kalimantan is still relatively low. One reason for IDG East Kalimantan is low because women's political participation is low. The Chairperson of the East Kalimantan Women's Solidarity Forum (Forsop), Priskilla Evalianita Randabunga revealed that women's involvement in politics is minimal because openness of access for women is not yet qualified. Almost all political spaces tend to be male dominated. This also relates to the stigma that women tend to be weak. It cannot be denied that women's struggle for gender equality faces cultural hurdles. Certain traditions, values and norms such as the entrenched myth of the unequal relationship between men and women are being upheld by many in opposition to the quest for gender equality [9].

In addition to legislative elections, there are also regional head elections. The regional head election, a local political event and a symbol of democratic government, is a contest for a legitimized power of regional leaders, who are given authority and responsibility to administer and lead the regional apparatus and development [10]. Considering the need for strong participation from the community to be directly involved in the election of their leaders, the election of regional heads becomes the important democratic momentum in Indonesia. At the lowest level, to participate is to be able to vote. In addition to voting, this study will analyze various forms of women's political participation in regional head elections, including voting, campaign, political discussion, and contacting.

\section{Research Method}

The research used a qualitative approach. This approach was obtained through the political participation of women activist in East Kalimantan Governor election 2008-2018. Informants selected based on following criterias:

1) Women activist in East Kalimantan who know about the active in community organization 
2) Women in government agency who know about women political participation in East Kalimantan

The study employs two data collection methods. First method is literature Studies/documents, using various sources start from books, journals, research results and media with relevant research topics. To obtain secondary data also conducted document / archive study. And the second method is in-depth interviews with selected informants through purposive sampling techniques. Interviews in this study were conducted with semi structured interview instruments.

\section{Result and Discussion}

In 2008 the East Kalimantan General Election Commission held the first direct General Election of the Regional Head (Governor), at that time 4 (four) candidates were nominated as Regional Heads, including Awang Farouk Ishak and Fariz Wazdy, Nusyirwan Ismail and Heru Bambang, Achmad Amin and Hadi Mulyadi, Yusuf SK and Luther Kombong. In 2013 the second governor election was held with three candidates were nominated as Regional Heads, including Awang Faroek Ishak and Mukmin Faisyal, Farid Wadjdy and Sofyan Alex getting number 2 and independent candidate were nominated, Imdaad Hamid and Ipong Muchlissoni. The Third, Governor election in 2018 has four of candidates were nominated as Regional Head Including Isran Noor and Hadi Mulyadi, Andi Sofyan Hasdam and Rizal Effendi, Rusmadi Wongso and Syafaruddin, Syaharie Jaang and Awang Ferdian Hidayat. Women are rarely involved in political maneuvers linked to the Pilkada (local election) arena. Until now there have been no women participating in the election as candidates for regional heads. Mrs. AJ, one of the IWAPI administrators, said there were several considerations of women as candidates for regional heads including financial, figure, and knowledge. A lack of funding had been identified as an important deferent to women who were considering entering politics especially as regional head candidates. But, women's political participation is not limited to just being a female regional head candidate.

Regional Head General Election in 2008 held simultaneously in 13 municipal districts in East Kalimantan, with voter data totaling 2,349,862 set by the General Election Commission of East Kalimantan Province consisting of 1,274.932 male voters and 1,074,932 female voters. Governor elections in 2013 experienced an increase in the number of voters to 2,794,297 consisting of $1,478,885$ male voters and 1,315,412 female voters. In the 2018 governor election there were $2,439,438$ voters consisting of 1,263,257 male voters and 1,176,181 female voters [11]. The number of female voters did not differ greatly from the number of male voters in the Province of East Kalimantan.

At the lowest level, to participate is to be able to vote, that is, to have the right to vote, to be in a position to go to the urns on voting days, and to have access to documents that will inform our choice [12]. Individuals who are interested in politics often start out voting. However, this cannot be done as the only indicator that women can vote. The form of participation does not only provide votes that can be approved because voting is the easiest participation. All the activists who became informants, they always voted in the East Kalimantan regional elections in 2008-2018. Activists are aware of the importance of voting in the elections.

Both the institutional aspects of Islamic piety, as well as the nature of Islamic piety as public practice, promote some women's participation in politics [13]. In addition to personal awareness, the organization where they are active in activities also supports the use of voting rights in the 
elections, for example in the Aisyiah religious organization. The Aisyiah does not allow their members to abstain. Their suffrage will determine East Kalimantan in the next five years. The Aisyiah recommends their members to use their voting rights. Besides Aisyiah, the East Kalimantan NU Muslimat religious organization also encouraged its members to get involved in voting to respect the democratic process. Democracy is obtained through a long process and not a small amount of money. NU Muslimat also conveys the risk of not participating in voting, that is, our voices can be misused.

One of the NU Muslimat organizers said two reasons women need to be involved in voting regional heads. First, women have the same voting rights as men. So there is no difference between the rights of men and women in voting. Second, all the policies that will be issued by the elected regional head seem not only to men but also women. The importance of voting was also conveyed by Mrs. F, tourism activist. She revealed that one vote was very important in influencing regional head elections "It is very important even if only one vote will affect it. One voice, we can influence each other"

In determining the selected regional head candidates there are various considerations. According Mrs. LM and Mrs. C, politician, the regional son (putra daerah) and the closeness factor are also considerations for selecting candidates for regional heads. Various considerations in choosing candidates for regional heads also conveyed one of the East Kalimantan Women's Caucus administrators. As a Muslim, she has the criteria for prospective Muslim leaders. As an organizational activist, she wants a leader who supports women, visionary, and has a good track record. The criteria of leaders who have preference for women are also considered by activists.

Campaign is the period right before citizens make a real political choice. This common knowledge typically heightens citizens' attention to politics in direct relation to the proximity of the event [14]. Campaigns can be done in a closed and open manner. In a closed and open campaign, the difference is the number of masses and their campaign sites. Open campaigns have more opportunities in gathering more mass and are in the open. In an open campaign method, there would ne more people can attend and listen to an explanation of their vision and mission which results in the formation of people's perceptions of candidates. The closed campaign is in a closed space with limited mass capacity. This campaign emphasizes community feedback rather than the quantity of people participating in political campaigns. In addition to being a campaign participant, there were also activists who became campaign committees. Activists involved in political organizations usually have the opportunity as campaign committees and even campaigners. They are looking for the masses to join the campaign. One of indicators usually used to judge whether a campaign is successful or not is the number of masses coming to the campaign of regional head candidates. The role of activists who can gather the masses is very important in the campaign. Women are more easily invited to participate in open campaigns. Mrs. M, family activists explained the reasons why women were more present than men in the campaign. The first, women have more free time. In addition, friendship and door prize factors during the open campaign. Women will be more easily invited by friends in the community organization that he follows. An attractive door prize during an open campaign also attracts women to join the campaign. But there is no opportunity to express aspirations in an open campaign. Meanwhile, opportunities to participate in closed campaigns for women are still very limited. Usually those who have the opportunity are women who are active in political parties.

In addition, campaigns held by supporting parties, activists can also be involved in campaigns in their respective organizations or communities. For example, it's when filling in an event. This was revealed by one of the East Kalimantan Muslim NU administrators. If there is event in community organization, it can also provide an opportunity for the regional head candidates to 
introduce himself and convey the vision and mission. This campaign activity certainly can save campaign costs for the candidates for regional heads.

Campaigns provide voters with the knowledge they need to make an informed vote choice and increase the likelihood of electoral participation [15]. In the campaign, the vision and mission programs will be carried out if the prospective regional head is elected. Mrs. SS, one of the organizers of the Greater Indonesia Women (Perempuan Indonesia Raya) who is also active in one of the political parties. She often follows campaigns both open and closed as success team. She said the governor's campaign was very important for the community especially around the open campaign to know who the governor we would choose. The extent to which the ability of the candidate governor and his mission vision is in accordance with what the community, especially the voters want.

Providing political participations and carrying out political campaigns are not only applicable for the public, statesmen can also easily carry out their works through social media. The election activities of the parties, election campaigns announcements and all kinds of actions for the public are presented from social media accounts [16]. Social media is now widely used by women. They can get to know the candidate's vision and mission through social media. Mrs. F, tourism activists also revealed that in the 2018 regional head election, the public could get to know the candidates for regional heads through social media. In the previous election, she only could see candidates from the news on television.

Political discussion is also something that is considered important by the community at the time before the regional head election, through political discussion the community can express their opinions on issues related to regional head elections. Formal political discussion participation is still considered to be limited to certain groups, for example people who are active in supporting parties for the regional head candidates. Formal political discussions held by regional head candidates or political parties are still rare for female activists involved. The success team of regional head candidates is still dominated by men, it is still very lack of opportunity for women to be involved in political discussions to formulate the policies of prospective regional heads. Political discussions discussing the policies that will be implemented when serving as regional head are still limited in the official success team also stated by one of the East Kalimantan NU Muslimat administrators. They were not involved in political discussions held by regional head candidates. According to Mrs. C, PAN East Kalimantan politician, the lack of involvement of women in political discussion was caused by a lack of opportunity. Fear of politics is also an obstacle to women's involvement. Politics still has a frightening stigma for women. Lack of confidence in women is a barrier in political discussions. Women often succumb to maintaining their aspirations in the debate. This was revealed in an interview at the East Kalimantan Women's Empowerment and Child Protection Agency.

Women are usually more often involved in informal political discussions. Mrs. B, a disability activist, stated that she encountered informal political discussions such as discussions with friends. This opinion is also in accordance with Mrs. F, tourism activist. She has never participated in a formal political discussion on policy. Political discussions can be started from informal discussions with friends in the community and their family. Political discussions that are often carried out by the community are not formal and with the intensity that is not routinely carried out, they often hold political discussions with casual conversations conducted in crowded places. It plays a vital role in shaping one's attitude and political orientation [17]. Political discussions can be started from discussions with friends in the community. Mothers who actively discuss in their community have the courage to express their opinions in a wider forum. The opinions that have been discussed are felt to represent the community. Women 
observe and criticize candidates for regional heads with friends. However, sometimes they do not realize that this activity is also a form of political participation

Political discussions can also be done in the family environment. Either who are active in political participation, such as Mrs. H, an education activist who often has political discussions with her husband, women need to be able to express their opinions and give input. The importance of political discussion for women in the family environment was also expressed by Mrs. F, tourism activist. According to her, women's opinions can influence family members. If women have opinions and issue aspirations for family members, father and children can follow.

Contacting is political participation carried out by citizens directly to government officials or political figures, whether done individually or in groups of very small numbers. From the interviews, not many activists were able to express their aspirations directly to the governor candidates. One of informant said that not all people have the opportunities to express their aspirations directly to prospective regional heads.

Activists who are active in political parties or become successful teams have the opportunity to contact prospective regional heads. Mrs. M, the family activist and also success team, also had the opportunity to express his opinion on social issues that have recently been in East Kalimantan regarding migrant sex workers from Doli. Mrs. C, Partai Amanat Nasional (PAN) politicians said that not all people have the opportunities to express their aspirations directly to prospective regional heads.

Activists who are active in community organizations that fight for women's political rights also make contact. The Indonesian Political Women Caucus (KPPI) in East Kalimantan contacted all regional head candidates, especially in 2018 election. As an organization that fights for women's rights in politics, they ensure that the gubernatorial candidates are leaders who care about women. Besides, they also want to know firsthand the vision of the mission and the programs that will be carried out by regional head candidates if later elected. In addition to the Political Women Caucus, NAPAS (Equivalent Women's Instincts) also contacted all candidates for regional heads. They offer programs that favor women and children. They divided the team to interpret the program to all candidates for the governor. Even before the fix advanced as a candidate for governor, they had taken an approach. They hope the governor includes programs that take sides with women and children into the vision and mission. Contacting organization for example the East Kalimantan Women's Caucus and NAPAS not only fighting for political rights, but they hope to be able to provide input on the right to side policies for women and children in various fields such as health, education, and others.

\section{Conclusion}

Since women made up a significant majority of the voters, their participation in electoral process is inevitable. Besides voting, there are various political participation form for women in PILKADA of Pemilihan Kepala Daerah (Local Government Election). By knowing the various forms of political participation such as voting, campaign, political discussion and contacting, it can be better to analyze the true nature of women's political participation. Lack of participation in various forms of political participation analyses helping determine steps for governments, political parties, and community organizations to increase women's political participation. 
Acknowledgements. We sincerely thank Ms. Laras Wijayanti for helping us to collect this research data

\section{References}

[1] Sulistiyanto, P. and Erb, M.: Deepening Democracy in Indonesia? Direct Elections for Local Leaders (Pilkada). Jakarta: ISEAS- Yusof Ishak Institute, (2009)

[2] Parvin, P. and Saunders, B.: "The Ethics of Political Participation: Engagement and Democracy in the 21st Century", Res Publica, Vol. 24, pp. 3-8, January (2018)

[3] Desposato, S. and Norrander, B. "The Gender Gap in Latin America: Contextual and Individual Influences on Gender and Political Participation”, British Journal of Political Science, Vol. 39, pp. 141-162, January (2009)

[4] N. Palaniswamy, R. Parthasarathy, and V. Rao, "Unheard Voices: The Challenge of Inducing Women's Civic Speech”. World Development, Vol. 115, pp. 64-77 (2019)

[5] Turcinskaite, A. B and Balciunas, J.: "Gender and Socioeconomic Influence on Civic and Political Participation as a Result of Socialization”, International Journal of Interdisciplinary Civic \& Political Studies, Vol. 11, pp. 1-12, April (2016)

[6] Graham Davies, S. D.: "Women in Politics in Indonesia in the Decade Post-Beijing", International Social Science Journal, Vol. 57 Issue 184, pp. 231-242 (2005)

[7] Kenny, M.: Gender and Political Recruitment: Theorizing Institutional Change. Basingstoke: Palgrave Macmillan (2003)

[8] Dahlerup, D and Freidenvall, L.: "Quotas as a 'Fast Track' to Equal Representation for Women, International Feminist Journal of Politics, Vol. 7, pp. 26-48 (2005)

[9] Robinson, K.M and Bessell, S: Women in Indonesia: Gender, Equity and Development (Vol. 8). Singapore: Institute of Southeast Asian Studies (2002)

[10] Winengan,: "Local Political Democratization Policy: Voter Participation in the Direct Regional Head Elections”, Jurnal Ilmu Sosial dan Ilmu Politik, Vol. 22 Issue 1, pp. 61-73 (2018)

[11] Komisi Pemilihan Umum: "Rekapitulasi Daftar Pemilih Tetap"[Online]. Available: https://kaltim.kpu.go.id/rekapitulasi-daftar-pemilih-tetap/ (2008)

[12] Berges, S. "Is Motherhood Compatible with Political Participation? Sophie de Grouchy's CareBased Republicanism”. Ethical Theory \& Moral Practice, Vol. 18, pp. 47-60 (2015)

[13] Rinaldo, R.: “The Islamic Revival and Women's Political Subjectivity in Indonesia, Women's Studies International Forum, Vol. 33, pp. 422-431 (2010)

[14] Brady, H. E, Johnston, R. and Sides, J.: "The Study of Political Campaigns. Capturing Campaign Effects, pp. 1-26 [Online]. Available: pdfs.semanticscholar.org (2006)

[15] Sudulich, L. and Trumm, S. "A Comparative Study of the Effects of Electoral Institutions on Campaigns", British Journal of Political Science, Vol. 49, pp. 1-19 (2019)

[16] Dasli, Y.: "Use of Social Media as a Tool for Political Communication in the Field of Politics", Sosyal Bilimler Arastirmalari Dergisi, Vol. 9, pp. 244-251 (2019)

[17] Afrilia, M, Surya, I and Dyastari, L.: "Partisipasi Politik Masyarakat dalam Pemilihan Bupati Kutai Kartanegara Tahun 2015 di Desa Manunggal Jaya Kecamatan Tenggarong Seberang”, eJournal Ilmu Pemerintahan, Vol. 5, pp. 1281-1294 (2017) 